\title{
Assessment of Undiscovered Conventional Oil and Gas Resources in the Eastern Mediterranean Area, 2020
}

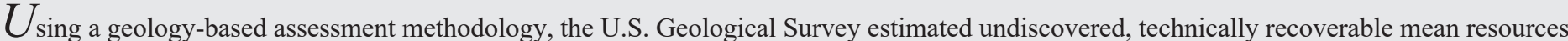
of 879 million barrels of conventional oil and 286.2 trillion cubic feet of conventional gas in the eastern Mediterranean area.

\section{Introduction}

The U.S. Geological Survey (USGS) quantitatively assessed the potential for undiscovered, technically recoverable conventional oil and gas resources in total petroleum systems and assessment units of the eastern Mediterranean area (fig. 1). The assessment encompasses the geographic areas of the Levantine Basin, Eratosthenes Platform, Nile Delta Basin, Herodotus Basin, and the Mediterranean Ridge.

The eastern Mediterranean area developed through a complex tectonic evolution and is the subject of ongoing research (Abdel Aal and others, 2000; Netzeband and others, 2006; Segev and others, 2011; Robertson and others, 2012, Cowie and Kusznir, 2013; Sagy and others, 2015; Granot, 2016; Inati and others, 2016; Segev and others, 2018; Steinberg and others, 2018). The tectonic evolution of the eastern Mediterranean began in the Triassic with rifting of the African-Arabian plate from Eurasia. Rifting continued through the Jurassic, resulting in highly extended continental crust across much of the Levantine Basin and the Nile Delta Basin. Oceanic crust formed in the Herodotus Basin and Mediterranean Ridge as the Tethys Ocean opened. Major sequences of petroleum source rocks were deposited across the continental margins during the Late Jurassic. The Cretaceous was characterized by passive-margin conditions, with carbonate platform development along the extended continental margins, and progradation of clastic sequences across the structurally complex, extended continental crust. The Eratosthenes Platform was one of the continental fragments separated from the African-Arabian plate and moved north as oceanic crust subducted beneath the southern margin of Eurasia, forming the Mediterranean Ridge accretionary complex. Carbonate platforms ranging in age from Cretaceous to Neogene formed along the margins of the Eratosthenes Platform. Repeated sea level changes during this time span led to the development of stacked carbonate platforms. Marine source rocks were deposited during the Cretaceous and Paleogene. Northward movement of the African-Arabian plate in the Paleogene signaled the beginning of closure of the Tethys Ocean. In the Oligocene and early Miocene, the ancestral Nile drainage was established, leading to northdirected clastic deposition in the Levantine Basin, Nile Delta Basin, and Herodotus Basin. The Eratosthenes Platform collided with the Cyprus arc in the Miocene, causing uplift with subsequent subaerial exposure and karst development across the extensive carbonate platforms. In the late Miocene, the northward movement of Africa resulted in closure of the Tethys seaway at Gibraltar and in the complete evaporation of Mediterranean seawater, leading to the deposition of hundreds of meters of late Miocene Messinian evaporites. Evaporites, being impervious to fluids, form important seals, as well as providing traps marginal to the salt structures, and, where salt has moved, provide pathways for fluids to migrate into post-salt reservoirs and traps (Al-Balushi and others, 2016). Neogene development of the Nile Delta depositional system resulted in further progradation of clastic sequences into the eastern Mediterranean area.

\section{Total Petroleum Systems and Assessment Units}

The USGS defined three total petroleum systems (TPS) encompassing eight conventional assessment units (AUs). The MesozoicCenozoic Composite TPS in the Levantine Basin was defined to include the Levantine Basin Mesozoic Reservoirs AU, the Levantine Basin Sub-Salt Cenozoic Reservoirs AU, and the Levantine Basin Post-Salt Cenozoic Reservoirs AU. The geologic model for the Levantine Basin Mesozoic Reservoirs AU is for oil and gas generated from Mesozoic

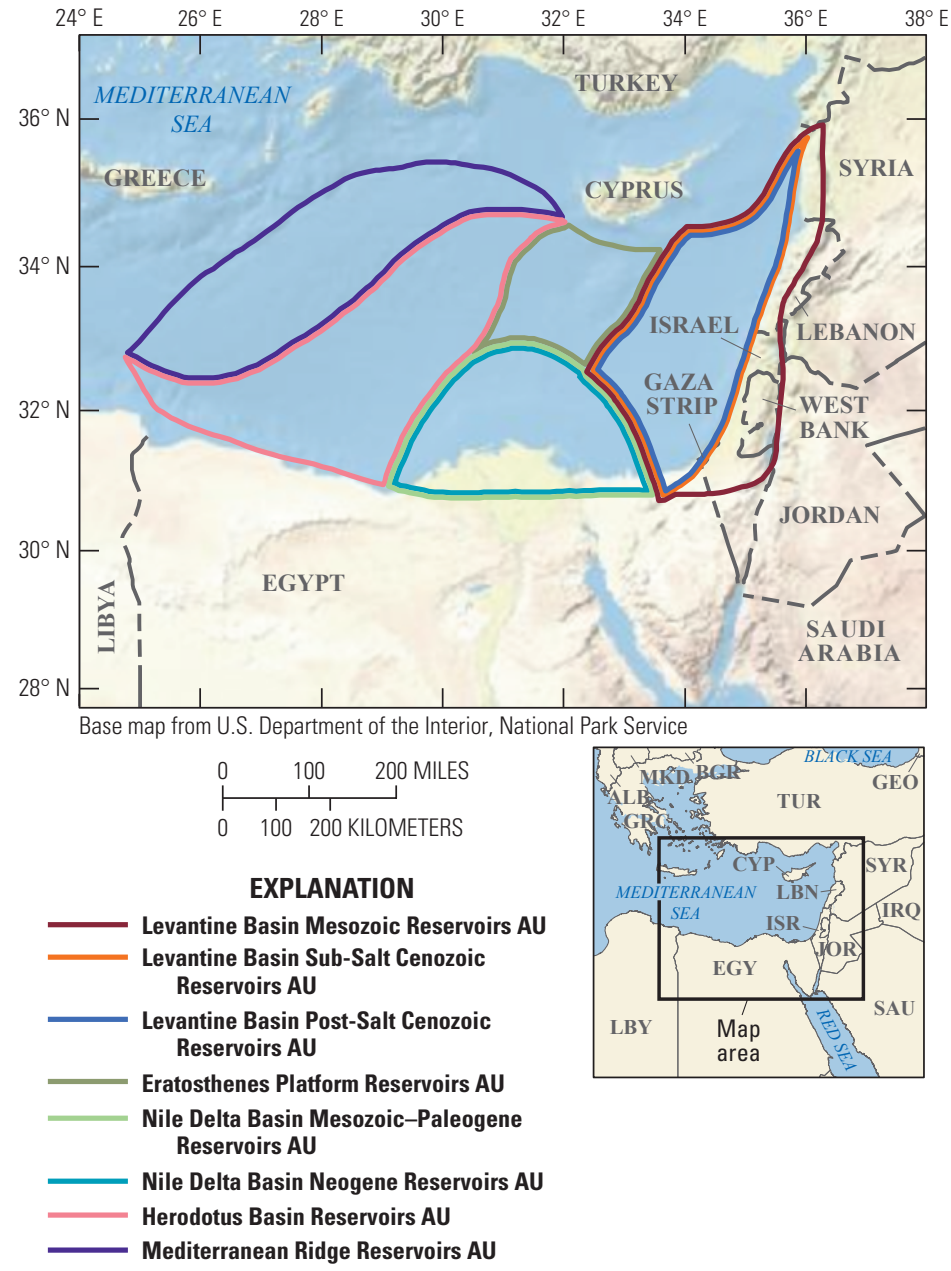

Figure 1. Map showing location of eight conventional assessment units (AUs) in the eastern Mediterranean area. Adjacent lines indicate a shared boundary at the outermost line. 
and Cenozoic sources to have migrated into sandstone and carbonate reservoirs within structural and stratigraphic traps, with oil focused along the eastern margin of the AU (Gardosh and others, 2011). The Levantine Basin Sub-Salt Cenozoic Reservoirs AU encompasses oil and gas generated from sub-salt sources and trapped in reservoirs within sub-salt structural and stratigraphic traps. The Levantine Basin Post-Salt Cenozoic Reservoirs AU includes gas from sub-salt sources that either migrated updip along faults, or biogenic gas generated and trapped within the post-salt section. Gas and oil accumulations are postulated to be mainly in structural traps but possibly also in stratigraphic traps (Gardosh and others, 2011; Skiple and others, 2012; Plummer and others, 2013).

The Mesozoic-Cenozoic Composite TPS includes the Nile Delta Basin Mesozoic-Paleogene Reservoirs AU, Nile Delta Basin Neogene Reservoirs AU, and the Eratosthenes Platform Reservoirs AU. The geologic model for the Nile Delta Basin Mesozoic-Paleogene Reservoirs $\mathrm{AU}$ is for oil and gas from several potential sources to have migrated into synrift carbonate platform margin reservoirs and synrift to postrift sandstone reservoirs formed within deltaic to deep-marine environments. The geologic model for the Nile Delta Basin Neogene Reservoirs AU is for thermogenic gas, biogenic gas, and minor oil to have migrated into deltaic, nearshore marine, slope-channel, and basin-floor fan, and into Messinian-age incised valley sandstone reservoirs (Abdel Aal and others, 2000; Vandré and others, 2007). The geologic model for the Eratosthenes Platform Reservoirs AU is for biogenic and thermogenic gas to have migrated updip and into carbonate karst reservoirs and reefs along the margins of the Eratosthenes Platform (Robertson, 1998; Esestime and others, 2016; Feld and others, 2017; Cozzi and others, 2018).

The Cenozoic TPS encompasses the Herodotus Basin Reservoirs AU and the Mediterranean Ridge Reservoirs AU. The geologic model for this TPS is for biogenic gas to have migrated into distal sandstone within northwest-prograding clastic sequences in the Herodotus Basin (Tari and others, 2012; Stanton and Macgregor, 2018), and for biogenic gas to have migrated into complexly faulted sandstone reservoirs within the Mediterranean Ridge accretionary complex (Camerlenghi and others, 1992; Fiduk, 2009). The possibility of inadequate seals in the Mediterranean Ridge Reservoirs AU led to the assignment of geologic risk. The assessment input data for eight AUs are summarized in table 1.

Table 1. Key input data for eight conventional assessment units in the eastern Mediterranean area.

[Shading indicates not applicable. AU, assessment unit; MMBO, million barrels of oil; BCFG, billion cubic feet of gas]

\begin{tabular}{|c|c|c|c|c|c|c|c|c|}
\hline \multirow{2}{*}{$\begin{array}{c}\text { Assessment input data- } \\
\text { Conventional AUs }\end{array}$} & \multicolumn{4}{|c|}{ Levantine Basin Mesozoic Reservoirs AU } & \multicolumn{4}{|c|}{ Levantine Basin Sub-Salt Cenozoic Reservoirs AU } \\
\hline & Minimum & Median & Maximum & $\begin{array}{l}\text { Calculated } \\
\text { mean }\end{array}$ & Minimum & Median & Maximum & $\begin{array}{l}\text { Calculated } \\
\text { mean }\end{array}$ \\
\hline Number of oil fields & 1 & 20 & 40 & 20.5 & & & & \\
\hline Number of gas fields & 1 & 70 & 210 & 74.4 & 1 & 140 & 280 & 143.4 \\
\hline Size of oil fields (MMBO) & 5 & 10 & 100 & 12.8 & & & & \\
\hline Size of gas fields (BCFG) & 30 & 60 & 10,000 & 185.7 & 30 & 72 & 30,000 & 365.6 \\
\hline AU probability & 1.0 & & & & 1.0 & & & \\
\hline \multirow[b]{2}{*}{$\begin{array}{l}\text { Assessment input data- } \\
\text { Conventional AUs }\end{array}$} & \multicolumn{4}{|c|}{ Levantine Basin Post-Salt Cenozoic Reservoirs AU } & \multicolumn{4}{|c|}{ Eratosthenes Platform Reservoirs AU } \\
\hline & Minimum & Median & Maximum & $\begin{array}{l}\text { Calculated } \\
\text { mean }\end{array}$ & Minimum & Median & Maximum & $\begin{array}{c}\text { Calculated } \\
\text { mean }\end{array}$ \\
\hline Number of oil fields & 1 & 5 & 15 & 5.3 & & & & \\
\hline Number of gas fields & 1 & 70 & 210 & 74.4 & 1 & 80 & 240 & 85.1 \\
\hline Size of oil fields (MMBO) & 5 & 8 & 20 & 8.4 & & & & \\
\hline Size of gas fields (BCFG) & 30 & 60 & 12,000 & 202 & 30 & 72 & 60,000 & 543.1 \\
\hline AU probability & 1.0 & & & & 1.0 & & & \\
\hline \multirow{2}{*}{$\begin{array}{l}\text { Assessment input data- } \\
\text { Conventional AUs }\end{array}$} & \multicolumn{4}{|c|}{ Nile Delta Basin Mesozoic-Paleogene Reservoirs AU } & \multicolumn{4}{|c|}{ Nile Delta Basin Neogene Reservoirs AU } \\
\hline & Minimum & Median & Maximum & $\begin{array}{l}\text { Calculated } \\
\text { Mean }\end{array}$ & Minimum & Median & Maximum & $\begin{array}{l}\text { Calculated } \\
\text { mean }\end{array}$ \\
\hline Number of oil fields & 1 & 50 & 150 & 53.2 & 1 & 20 & 40 & 20.5 \\
\hline Number of gas fields & 1 & 200 & 400 & 204.9 & 1 & 500 & 1,000 & 512.2 \\
\hline Size of oil fields (MMBO) & 1 & 4 & 200 & 8.2 & 1 & 4 & 100 & 6.6 \\
\hline Size of gas fields (BCFG) & 6 & 36 & 10,000 & 161.9 & 6 & 36 & 15,000 & 201 \\
\hline AU probability & 1.0 & & & & 1.0 & & & \\
\hline \multirow{2}{*}{$\begin{array}{c}\text { Assessment input data- } \\
\text { Conventional AUs }\end{array}$} & \multicolumn{4}{|c|}{ Herodotus Basin Reservoirs AU } & \multicolumn{4}{|c|}{ Mediterranean Ridge Reservoirs AU } \\
\hline & Minimum & Median & Maximum & $\begin{array}{l}\text { Calculated } \\
\text { Mean }\end{array}$ & Minimum & Median & Maximum & $\begin{array}{c}\text { Calculated } \\
\text { mean }\end{array}$ \\
\hline \multicolumn{9}{|l|}{ Number of oil fields } \\
\hline Number of gas fields & 1 & 70 & 210 & 74.4 & 1 & 25 & 75 & 26.6 \\
\hline \multicolumn{9}{|l|}{ Size of oil fields (MMBO) } \\
\hline Size of gas fields (BCFG) & 30 & 60 & 20,000 & 260.1 & 30 & 60 & 2,000 & 102 \\
\hline AU probability & 1.0 & & & & 0.9 & & & \\
\hline
\end{tabular}


Undiscovered Resources Summary

The USGS quantitatively assessed undiscovered oil and gas resources within eight conventional assessment units in the eastern Mediterranean area (table 2). The estimated mean totals for conventional resources are 879 million barrels of oil (MMBO) with an F95-F5 range from 449 to 1,472 MMBO; 286,174 billion cubic feet of gas (BCFG), or 286.2 trillion cubic feet of gas, with an F95-F5 range from 138,273 to 494,133 BCFG; and 2,207 million barrels of natural gas liquids (MMBNGL), or 2.2 billion barrels, with an F95-F5 range from 1,247 to 3,449 MMBNGL.

Table 2. Results for eight conventional assessment units in the eastern Mediterranean area.

[Results shown are fully risked estimates. F95 represents a 95-percent chance of at least the amount tabulated; other fractiles are defined similarly. Shading indicates not applicable. MMBO, million barrels of oil; BCFG, billion cubic feet of gas; NGL, natural gas liquids; MMBNGL, million barrels of natural gas liquids]

\begin{tabular}{|c|c|c|c|c|c|c|c|c|c|c|c|c|c|c|}
\hline \multirow{3}{*}{$\begin{array}{c}\text { Total petroleum } \\
\text { systems and } \\
\text { assessment units (AUs) }\end{array}$} & \multirow{3}{*}{$\begin{array}{c}\text { AU } \\
\text { prob- } \\
\text { ability }\end{array}$} & \multirow{3}{*}{$\begin{array}{l}\text { Accum- } \\
\text { ulation } \\
\text { type }\end{array}$} & \multicolumn{12}{|c|}{ Total undiscovered resources } \\
\hline & & & \multicolumn{4}{|c|}{ Oil (MMBO) } & \multicolumn{4}{|c|}{ Gas (BCFG) } & \multicolumn{4}{|c|}{ NGL (MMBNGL) } \\
\hline & & & F95 & F50 & F5 & Mean & F95 & F50 & F5 & Mean & F95 & F50 & F5 & Mean \\
\hline \multicolumn{15}{|c|}{ Mesozoic-Cenozoic Composite Total Petroleum System (Levantine Basin Province) } \\
\hline \multirow{2}{*}{$\begin{array}{l}\text { Levantine Basin Meso- } \\
\text { zoic Reservoirs AU }\end{array}$} & \multirow{2}{*}{1.0} & Oil & 161 & 253 & 389 & 261 & 95 & 152 & 237 & 157 & 1 & 1 & 1 & 1 \\
\hline & & Gas & & & & & 5,449 & 12,660 & 26,148 & 13,817 & 14 & 31 & 66 & 35 \\
\hline $\begin{array}{l}\text { Levantine Basin } \\
\text { Sub-Salt Cenozoic } \\
\text { Reservoirs AU }\end{array}$ & 1.0 & Gas & & & & & 25,763 & 49,403 & 88,371 & 52,222 & 76 & 148 & 267 & 157 \\
\hline \multirow{2}{*}{$\begin{array}{l}\text { Levantine Basin } \\
\text { Post-Salt Cenozoic } \\
\text { Reservoirs AU }\end{array}$} & \multirow[b]{2}{*}{1.0} & Oil & 24 & 42 & 75 & 45 & 14 & 25 & 46 & 27 & 0 & 0 & 0 & 0 \\
\hline & & Gas & & & & & 5,696 & 13,694 & 29,123 & 15,059 & 0 & 0 & 0 & 0 \\
\hline \multicolumn{15}{|c|}{ Mesozoic-Cenozoic Composite Total Petroleum System (Nile Delta Basin Province) } \\
\hline $\begin{array}{l}\text { Eratosthenes Platform } \\
\text { Reservoirs AU }\end{array}$ & 1.0 & Gas & & & & & 13,624 & 39,795 & 99,572 & 46,181 & 20 & 59 & 153 & 69 \\
\hline \multirow{2}{*}{$\begin{array}{l}\text { Nile Delta Basin } \\
\text { Mesozoic-- } \\
\text { Paleogene } \\
\text { Reservoirs AU }\end{array}$} & \multirow[b]{2}{*}{1.0} & Oil & 193 & 409 & 788 & 438 & 231 & 491 & 946 & 526 & 3 & 6 & 12 & 7 \\
\hline & & Gas & & & & & 18,525 & 32,129 & 51,984 & 33,262 & 389 & 675 & 1,093 & 699 \\
\hline \multirow{2}{*}{$\begin{array}{l}\text { Nile Delta Basin Neo- } \\
\text { gene Reservoirs AU }\end{array}$} & \multirow{2}{*}{1.0} & Oil & 71 & 128 & 220 & 135 & 177 & 320 & 551 & 336 & 3 & 5 & 8 & 5 \\
\hline & & Gas & & & & & 61,992 & 99,925 & 153,088 & 102,792 & 741 & 1,198 & 1,849 & 1,234 \\
\hline \multicolumn{15}{|c|}{ Cenozoic Total Petroleum System (Mediterranean Basin Province) } \\
\hline $\begin{array}{l}\text { Herodotus Basin } \\
\text { Reservoirs AU }\end{array}$ & 1.0 & Gas & & & & & 6,707 & 17,249 & 39,227 & 19,352 & 0 & 0 & 0 & 0 \\
\hline $\begin{array}{l}\text { Mediterranean Ridge } \\
\text { Reservoirs AU }\end{array}$ & 0.9 & Gas & & & & & 0 & 2,353 & 4,840 & 2,443 & 0 & 0 & 0 & 0 \\
\hline $\begin{array}{l}\text { Total undiscovered } \\
\text { conventional } \\
\text { resources }\end{array}$ & & & 449 & 832 & 1,472 & 879 & 138,273 & 268,196 & 494,133 & 286,174 & 1,247 & 2,123 & 3,449 & 2,207 \\
\hline
\end{tabular}

\section{References Cited}

Abdel Aal, A., El-Barkooky, A., Gerrits, M., Meyer, H., Schwander, M., and Zaki, H., 2000, Tectonic evolution of the Eastern Mediterranean Basin and its significance for hydrocarbon prospectivity in the ultradeepwater of the Nile Delta: The Leading Edge, v. 19, no. 10 , p. $1086-1102$.

Al-Balushi, A.N., Neumaier, M., Fraser, A.J., and Jackson, C.A.-L., 2016, The impact of the Messinian salinity crisis on the petroleum system of the Eastern Mediterranean-A critical assessment using 2D petroleum system modeling: Petroleum Geoscience, v. 22, no. 4, p. 357-379. [Also available at https://doi.org/10.1144/petgeo2016-054.]
Camerlenghi, A., Cita, M.B., Hieke, W., and Ricchiuto, T., 1992, Geological evidence for mud diapirism on the Mediterranean Ridge accretionary complex: Earth and Planetary Science Letters, v. 109, nos. 3-4, p. 493-504. [Also available at https://doi.org/10.1016/ 0012-821X(92)90109-9.]

Cowie, L., and Kusznir, N.J., 2013, Crustal thickness, oceanic lithosphere distribution and OCT structure for the eastern Mediterranean from gravity inversion: American Association of Petroleum Geologists, Search and Discovery Article No. 30278, 26 p., accessed January 19, 2021, at https://www.searchanddiscovery.com/documents/2013/ 30278cowie/ndx_cowie.pdf. 
Cozzi, A., Cascone, A., Bertelli, L., Bertello, F., Brandolese, S., Minervini, M., Ronchi, P., Ruspi, R., and Harby, H., 2018, Zohr giant gas discovery-A paradigm shift in Nile Delta and East Mediterranean exploration: American Association of Petroleum Geologists, Search and Discovery Article No. 20414, 22 p., accessed January 15, 2021, at https://www.searchanddiscovery.com/pdfz/documents/2018/ 20414cozzi/ndx_cozzi.pdf.html.

Esestime, P., Hewitt, A., and Hodgson, N., 2016, Zohr-A newborn carbonate play in the Levantine Basin, East-Mediterranean: First Break, v. 34, no. 2, p. 87-93. [Also available at https://doi.org/10.3997/ 1365-2397.34.2.83912.]

Feld, C., Mechie, J., Hübscher, C., Hall, J., Nicolaides, S., Gurbuz, C., Bauer, K., Louden, K., and Weber, M., 2017, Crustal structure of the Eratosthenes Seamount, Cyprus and S. Turkey from an amphibian wide-angle seismic profile: Tectonophysics, v. 700-701, p. 32-59. [Also available at https://doi.org/10.1016/j.tecto.2017.02.003.]

Fiduk, J.C., 2009, Evaporites, petroleum exploration, and the Cenozoic evolution of the Libyan shelf margin, central North Africa: Marine and Petroleum Geology, v. 26, no. 8, p. 1513-1527. [Also available at https://doi.org/10.1016/j.marpetgeo.2009.04.006.]

Gardosh, M., Weimer, P., and Flexer, A., 2011, The sequence stratigraphy of Mesozoic successions in the Levant margin, southwestern Israel-A model for the evolution of southern Tethys margins: American Association of Petroleum Geologists Bulletin, v. 95, no. 10, p. 1763-1793. [Also available at https://doi.org/10.1306/ 02081109135.]

Granot, R., 2016, Palaeozoic oceanic crust preserved beneath the eastern Mediterranean: Nature Geoscience, v. 9, no. 9, p. 701-705. [Also available at https://doi.org/10.1038/ngeo2784.]

Inati, L., Zeyen, H., Nader, F.H., Adelinet, M., Sursock, A., Rahhal, M.E., and Roure, F., 2016, Lithospheric architecture of the Levant Basin (Eastern Mediterranean region) - A 2D modeling approach: Tectonophysics, v. 693, p. 143-156. [Also available at https://doi.org/ 10.1016/j.tecto.2016.10.030.]

Netzeband, G.L., Gohl, K., Hübscher, C.P., Ben-Avraham, Z., Dehghani, G.A., Gajewski, D., and Liersch, P., 2006, The Levantine Basin-Crustal structure and origin: Tectonophysics, v. 418, nos. 3-4, p. 167-188. [Also available at https://doi.org/10.1016/ j.teco.2006.01.001.]

Plummer, M., Belopolsky, A., Fish, P., and Norton, M., 2013, Tectonostratigraphic evolution and exploration potential of the Northern Levant Basin: American Association of Petroleum Geologists, Search and Discovery No. 10516, 20 p., accessed January 19, 2012, at https://www.searchanddiscovery.com/documents/2013/ 10516plummer/ndx_plummer.pdf.
Robertson, A.H.F., 1998, Tectonic significance of the Eratosthenes Seamount-A continental fragment in the process of collision with a subduction zone in the eastern Mediterranean (Ocean Drilling Program Leg 160): Tectonophysics, v. 298, nos. 1-3, p. 63-82. [Also available at https://doi.org/10.1016/S0040-1951(98)00178-4.]

Robertson, A.H.F., Parlak, O., and Ustaömer, T., 2012, Overview of the Palaeozoic-Neogene evolution of Neotethys in the Eastern Mediterranean region (southern Turkey, Cyprus, Syria): Petroleum Geoscience, v. 18, no. 4, p. 381-404. [Also available at https://doi.org/10.1144/ petgeo2011-091.]

Sagy, Y., Gvirtzman, Z., Reshef, M., and Makovsky, Y., 2015, The enigma of the Jonah high in the middle of the Levant Basin and its significance to the history of rifting: Tectonophysics, v. 665, p. 186-198. [Also available at https://doi.org/10.1016/j.tecto.2015.09.037.]

Segev, A., Schattner, U., and Lyakhovsky, V., 2011, Middle-Late Eocene structure of the southern Levant continental marginTectonic motion versus global sea-level change: Tectonophysics, v. 499, nos. 1-4, p. 165-177. [Also available at https://doi.org/ 10.1016/j.tecto.2011.01.006.]

Segev, A., Sass, E., and Schattner, U., 2018, Age and structure of the Levant Basin, Eastern Mediterranean: Earth-Science Reviews, v. 182, p. 233250. [Also available at https://doi.org/10.1016/j.earscirev.2018.05.011.]

Skiple, C., Anderson, E., and Fürstenau, J., 2012, Seismic interpretation and attribute analysis of the Herodotus and the Levantine Basin, offshore Cyprus and Lebanon: Petroleum Geoscience, v. 18, no. 4, p. 433-442. [Also available at https://doi.org/10.1144/petgeo2011-072.]

Stanton, S., and Macgregor, D., 2018, Petroleum potential of the Herodotus Basin-Applying regional analogues to predict plays and reduce potential risk: American Association of Petroleum Geologists, Search and Discovery Article No. 11169, 17 p., accessed January 19, 2021, at https:/www.searchanddiscovery.com/pdfz/documents/2018/ 11169stanton/ndx_stanton.pdf.html.

Steinberg, J., Roberts, A.M., Kusznir, N.J., Schafer, K., and Karcz, Z., 2018, Crustal structure and post-rift evolution of the Levant Basin: Marine and Petroleum Geology, v. 96, p. 522-543. [Also available at https://doi.org/10.1016/j.marpetgeo.2018.05.006.]

Tari, G., Kohazy, R., Hannke, K., Hussein, H., Novotny, B., and Mascle, J., 2012, Examples of deep-water play types in the Matruh and Herodotus basins of NW Egypt: The Leading Edge, v. 31, no. 7, p. 816-823. [Also available at https://doi.org/10.1190/tle31070816.1.]

Vandré, C., Cramer, B., Gerling, P., and Winsemann, J., 2007, Natural gas formation in the western Nile Delta (Eastern Mediterranean)-Thermogenic versus microbial: Organic Geochemistry, v. 38, no. 4, p. 523-539. [Also available at https://doi.org/10.1016/ j.orggeochem.2006.12.006.]

\section{For More Information}

Assessment results are also available at the USGS Energy Resources Program website at https://energy.usgs.gov.

\section{Eastern Mediterranean Assessment Team}

Christopher J. Schenk, Tracey J. Mercier, Thomas M. Finn, Cheryl A. Woodall, Kristen R. Marra, Heidi M. Leathers-Miller, Phuong A. Le, and Ronald M. Drake II 